\title{
PENGARUH KOMPENSASI TERHADAP KINERJA GURU DI SMP NEGERI 3 BATUSANGKAR
}

\author{
Alisyah Pitri \\ Peneliti Independen IAIN Batusangkar \\ e-mail: a alisyapitri23@yahoo.co.id
}

\begin{abstract}
This study aimed at determining the influence of compensation on teachers' performance in State Secondary School 3 Batusangkar. The method used was a quantitative. The population in this study were all teachers of civil servants in State Secondary School 3 Batusangkar which consist of 43 people. Analyzer used in this research was simple linear regression, coefficient of determinant, and t test. Data processing using SPSS statistics 20 for windows. Based on the results of the study, it was known that simultaneously the compensation has a significant and positive effect on teachers' performance. The result from simple linear that constant score equal to 100,008 and coefficient score of compensation equal to 0,378 this indicate that there is significant and positive influence to teachers' performance in State Secondary School 3 Batusangkar. The result of determinant coefficient can be seen that the involvement of compensation variable to teachers' performance is $17,1 \%$. Result of $t$-test where $t$-count $>t$-table $(2,905>2,701)$ or sig. $<0,01(0,000<0,01)$ which means that Ha is accepted and Ho is rejected.
\end{abstract}

Keywords: Compensation, Teachers' Performance, State Secondary School 3 Batusangkar

\section{PENDAHULUAN}

Guru memegang peran yang sangat penting dan menentukan dalam pelaksanaan pembelajaran di madrasah. Dengan demikian kinerja guru harus terus ditingkatkan agar dapat melaksanakan tugas dan fungsinya mengemban amanat pendidikan seperti yang telah digariskan dalam Undang-Undang Sistem Pendidikan Nasional. Berbagai upaya dan strategi harus dilakukan dengan baik terencana agar kinerja guru terus meningkat dan dapat mencapai tujuan pendidikan yang telah direncanakan.

Kinerja berasal dari pengertian performance. Ada pula yang memberikan pengertian performance sebagai hasil kerja atau prestasi kerja. Namun, sebenarnya kinerja mempunyai makna yang lebih luas, bukan hanya hasil kerja, tetapi termasuk bagaimana proses pekerjaan berlangsung. Armstrong dan Baron (dalam Wibowo, 2013, 7) mengatakan bahwa kinerja merupakan hasil pekerjaan yang mempunyai hubungan kuat dengan tujuan strategis organisasi, kepuasan konsumen, dan memberikan konstribusi pada ekonomi.

Jasmani dan Mustofa (2013, 156) mengatakan bahwa kinerja guru adalah hasil kerja yang dapat dicapai oleh seorang guru dilembaga pendidikan sesuai dengan tugas dan tanggung jawabnya dalam mencapai tujuan pendidikan. Dengan kata lain, hasil kerja yang dicapai seseorang dalam melaksanakan tugastugas yang dibebankan kepadanya didasarkan atas kecakapan, pengalaman, dan 
kesungguhannya. Berkaitan dengan kinerja guru dalam melaksanakan kegiatan belajar mengajar, maka dapat dikemukakan Tugas Keprofesionalan Guru menurut UndangUndang Republik Indonesia Nomor 14 tahun 2005 pasal 20 (a) Tentang Guru dan Dosen adalah merencanakan pembelajaran, melaksanakan proses pembelajaran yang bermutu, serta menilai dan mengevaluasi hasil pembelajaran.

Kenyataan yang tidak dapat disangkal bahwa motivasi dasar bagi kebanyakan orang menjadi pegawai pada suatu organisasi tertentu adalah untuk mencari nafkah. Berarti apabila disatu pihak seseorang menggunakan pengetahuan, keterampilan, tenaga dan sebagian waktunya untuk berkarya pada suatu organisasi,di lain pihak ia mengharapkan menerima kompensasi/kompensasi tertentu. Berangkat dari pandangan demikian, dewasa ini masalah kompensasi dipandang sebagai salah satu tantangan yang harus dihadapi oleh manajemen suatu organisasi.

Seseorang bekerja memberikan waktu dan tenaganya kepada organisasi dan sebagai kontra prestasinya, organisasi memberikan imbalan atau kompensasi yang bentuknya dapat sangat bervariasi. Sistem yang dipergunakan organisasi dalam memberikan imbalan tersebut dapat mempengaruhi motivasi kerja dan kepuasan kerja karyawan. Kesalahan dalam menerapkan sistem penghargaan akan berakibat timbulnya demotivasi dan tidak adanya kepuasan kerja di kalangan pekerja. Apabila hal tersebut terjadi dapat menyebabkan turunnya kinerja baik pekerja maupun organisasi. Dalam kenyataannya, setiap organisasi menerapkan sistem kompensasi secara fleksibel dan bebas sesuai dengan kondisi masing-masing. Sistem mana yang dirasa tepat untuk memberikan kompensasi kepada pekerja dengan harapan dapat meningkatkan kinerja dan menumbuhkan kepuasan kerjanya.

Didalam kompensasi terdapat sistem insentif yang menghubungkan kompensasi dengan kinerja. Dengan kompensasi penghargaan yang diberikan kepada pekerja berdasarkan kinerja yang dihasilkannya dan bukan berdasarkan senioritas atau jumlah jam kerja. Dilihat dari cara pemberiannya, kompensasi dapat merupakan kompensasi langsung dan kompensasi tidak langsung. Kompensasi langsung merupakan kompensasi manajemen seperti upah dan gaji atau pay for performance, seperti insentif dan Gain sharing. Sementara itu, kompensasi tidak langsung dapat berupa tunjangan atau jaminan keamanan dan kesehatan (Wibowo, 2013, 348).

Kompensasi sangat penting bagi guru, hal ini karena kompensasi merupakan sumber penghasilan bagi mereka dan keluarganya, selain itu pemberian kompensasi juga 
berdampak terhadap kondisi psikologis bagi guru itu sendiri dalam melaksanakan tugasnya sebagai pendidik.

Berdasarkan hasil observasi dan wawancara yang peneliti lakukan dengan wakil kurikulum Ibu Guspita Hutri, S.Pd di SMPN 3 Batusangkar Selasa, pukul 10.00 Wib, tanggal 27 September 2016 dilihat dari hasil pengamatan bahwa masih ada tenaga kependidikan dan pendidik yang bekerja di SMPN 3 Batusangkar tidak tepat waktu sesuai jadwal masuk yang telah ditentukan. Karena jam presensi pukul 07.15 wib sudah berada dilingkungan sekolah namun pada kenyataannya beberapa pendidik dan tenaga kependidikan datang ke sekolah pukul 07.20 wib dan bahkan ada yang pukul 07.30 wib beberapa orang pendidik dan tenaga kependidikan jam pulangnya pun tidak sesuai jadwal pulang, ada yang lebih cepat dari jadwal sebenarnya. Kemudian untuk pengembangan diri yang difasilitasi pemerintah terbatas tidak semua guru yang mengikuti karena dibatasi jumlahnya. Selanjutnya untuk pemberian penghargaan bagi guru berprestasi tidak berjalan optimal dengan demikian diduga mempengaruhi kinerja guru (wawancara dengan wakil kurikulum Ibu Guspita Hutri, Rabu, pukul 11.00 Wib 05 Oktober 2016).

Oleh karena itu dalam penelitian ini akan dikaji pengaruh kompensasi terhadap kinerja guru di SMP N 3 Batusangkar, sehingga perumusan masalah pada penelitian ini adalah "Bagaimana Pengaruh Kompensasi Terhadap Kinerja Guru di SMPN 3 Batusangkar?"

\section{KOMPENSASI}

Hasibuan (2013: 118) mengatakan kompensasi adalah semua pendapatan yang berbentuk uang, barang langsung atau tidak langsung yang diterima karyawan sebagai imbalan atas jasa yang diberikan kepada perusahaan. Kompensasi merupakan kontra prestasi terhadap penggunaan tenaga atau jasa yang telah diberikan oleh tenaga kerja. Kompensasi merupakan jumlah paket yang ditawarkan organisasi kepada pekerja sebagai imbalan atas penggunaan tenaga kerjanya (Wibowo, 2007: 348).

Nurzaman (2014: 179) mengatakan kompensasi adalah sesuatu yang diterima para karyawan sebagai balas jasa atas prestasinya dalam melaksankan tugas. Pemberian kompensasi bertujuan membantu pegawai memenuhi kebutuhan diluar kebutuhan rasa adil, serta meningkatkan motivasi kerja karyawan dalam menyelesaikan tugas-tugas yang menjadi tanggung jawabnya. Upah atau gaji menekankan pada balas jasa yang bersifat finansial, sedangkan kompensasi mencakup balas jasa finansial maupun non-finansial. Kompensasi merupakan pemberian balas jasa, baik secara langsung berupa uang (finansial) 
maupun tidak langsung berupa penghargaan (non-finansial).

Mulyasa (Marzuki, 2008: 17) (dalam Prasojo, 2012: 13) yaitu "kompensasi adalah balas jasa yang diberikan dinas pendidikan dan sekolah kepada tenaga kependidikan, yang dapat dinilai dengan uang dan mempunyai kecenderungan diberikan secara tetap".

\section{KINERJA}

Jasmani dan Mustafa (2013: 155) mengatakan bahwa istilah kinerja berasal dari kata jobperformance atau actual performance (prestasi kerja atau prestasi sesungguhnya yang dicapai oleh seseorang). Supardi (2013: 69) mengatakan bahwa kinerja guru juga dapat ditunjukkan dari seberapa besar kompetensikompetensi yang dipersyaratkan dipenuhi. Kinerja merupakan terjemahan dari bahasa Inggris, work performance atau job performance. Kinerja atau prestasi kerja diartikan sebagai ungkapan kemampuan yang didasari oleh pengetahuan sikap, keterampilan, dan motivasi dalam menghasilkan sesuatu. Kinerja adalah sesuatu yang dicapai atau prestasi yang diperlihatkan atau kemampuan bekerja. Dengan kata lain kinerja dapat diartikan sebagai prestasi kerja (Jasmani dan Mustofa, 2013:156).

Torang (2013: 74) mengatakan bahwa kinerja (performance) adalah kuantitas dan atau kualitas hasil kerja individu atau sekelompok di dalam organisasi dalam melaksanakan tugas pokok dan fungsi yang berpedoman pada norma, standar operasional prosedur, kriteria dan ukuran yang telah ditetapkan atau yang berlaku dalam organisasi..

Berdasarkan penjabaran di atas diduga kompensasi dapat berpengaruh terhadap kinerja guru, jika sesuai kompensasi guru dengan hasil kerjanya maka semakin meningkat kinerja guru dan jika kompensasi tidak sesuai maka kinerja guru akan menurun.




Berdasarkan bagan gambar 1 tersebut, maka penelitian ini akan mendeskripsikan pengaruh pemberian kompensasi terhadap kinerja guru di mana kompensasi sebagai variabel independen atau variabel bebas yang mempengaruhi atau yang menjadi sebab perubahannya atau timbulnya variabel dependen atau variabel terikat, dalam hal ini adalah kinerja guru. Maka penulis tertarik untuk melakukan penelitian pengaruh kompensasi terhadap kinerja guru.

Berdasarkan latar belakang, teori kompensasi dan kinerja, penelitian yang relevan, defenisi oprasional dan kerangka pemikiran maka penelitian ini mengemukakan hipotesis sebagai berikut:

1. $\mathrm{Ha}=$ Kompensasi berpengaruh signifikan dan positif terhadap kinerja guru di SMPN 3 Batusangkar

2. $\mathrm{Ho}=$ Kompensasi tidak berpengaruh signifikan dan positif terhadap kinerja guru di SMPN 3 Batusangkar

\section{METODE PENELITIAN}

Jenis penelitian yang digunakan dalam penelitian ini adalah pendekatan kuantitatif. Lokasi penelitian ini dilakukan pada SMPN 3 Batusangkar. Penelitian ini dilakukan pada bulan September sampai Oktober tahun 2016. Untuk data awal diperoleh dari hasil wawancara bersama ibu Guspita Hutri, S.Pd selaku Wakil Kurikulum SMPN 3
Batusangkar. Kemudian dilanjutkan dengan penelitian penyebaran angket dari tanggal 9-14 Januari 2017 ke seluruh guru di SMPN 3 Batusangkar.Teknik pengambilan data dengan menggunakan kuisioner tertutup yang disusun dalam bentuk skala Likert dan dimodifikasi dengan empat alternative jawaban: Selalu (SL), Sering (SR), Kadang- kadang (KK), dan Tidak pernah (TP) (Sugiyono, 2014:168).

\section{TEKNIK ANALISIS DATA}

a. Analisis Deskriptif

Pada tahap ini, data yang telah diperoleh dari penelitian dideskripsikan menurut masing-masing variabel dengan menggunakan bantuan SPSS versi 20 untuk mendapatkan mean/rata-rata (M), standar deviasi (SD), modus (Md), dan median (Me). Distribusi frekuensi data dibuat dengan membuat kelas interval.

Berikut ini analisis deskriptif yang digunakan dalam penelitian ini:

1) Menentukan distribusi frekuensi

a) Rentang kelas = data terbesar dikurang data terkecil

b) Banyak kelas $=1+(3,3) \log n$

c) Panjang kelas = Rentang / banyak kelas

d) Tabel distribusi frekuensi

2) Menentukan Mean

$$
\mathrm{Y}=\sum \mathrm{Y} / \mathrm{n}
$$

a) Menentukan Median 


$$
\mathrm{Mdn}=\frac{\mathrm{b}+\mathrm{p}\left[^{1 / 2} \mathrm{~N}-\mathrm{F}\right]}{\mathrm{t}}
$$

b) Menentukan Modus data yang memiliki frekuensi terbanyak untuk variabel yang ada.

c) Menentukan Standar Deviasi

d) $\mathrm{SD}=\frac{\sqrt{\Sigma \mathrm{Y}^{2} \mathrm{n} 1-(\mathrm{Yi})^{2} / \mathrm{n}}}{\mathrm{H}-1}$

b. Persyaratan Analisis

1) Uji Normalitas

Pengolahan data statistik dalam penelitian ini dengan menggunakan aplikasi program komputer atau software Statistical Product and Service Solution (SPSS) 20 for Windows dengan kriteria sebagai berikut:

Jika sig $>\alpha$ berarti data berdistribusi normal

Jika sig $<\alpha$ berarti data tidak berdistribusi normal

2) Uji Linieritas

Liniearitas diukur mengetahui liniearitas hubungan antara veriabel bebas dengan terikat, yaitu kompensasi $(\mathrm{X})$, dan kinerja guru (Y). Kriteria yang digunakan adalah apabila harga $\mathrm{p}$ pada lajur dev. from linearty lebih besar dari harga $\alpha=0,01$ dinyatakan bahwa regresinya linier, dan sebaliknya jika $\mathrm{p}$ lebih kecil dari harga $\alpha=0,01$ dinyatakan bahwa regresinya tidak linier.

Teknik analisis yang digunakan dalam penelitian ini adalah analisis Korelasi Pearson Product Moment (PPM). Analisis ini akan digunakan dalam menguji besarnya hubungan dan kontribusi variabel $\mathrm{X}$ terhadap $\mathrm{Y}$. Analisis Korelasi yang digunakan adalah Pearson Product Moment (PPM), dengan rumus:

$$
R x y=\frac{n(\Sigma x y)-(\Sigma x)(\Sigma y)}{\sqrt{\left\{n \Sigma x^{2}-(\Sigma x)^{2}\right\}\left\{n \Sigma y^{2}-\left(\Sigma y^{2}\right)\right\}}}
$$

Korelasi PPM dilambangkan (r) dengan ketentuan nilai $r$ tidak lebih dari harga $(-1 \leq \mathrm{r} \leq+1)$. Apabila nilai $\mathrm{r}=-1$ artinya korelasinya negatif sempurna; $r=$ 0 artinya tidak ada korelasi; dan $r=1$ berarti korelasinya sangat kuat. Dapat dilihat dari tabel yang ada dibawah ini.

Table 1.

Pedoman Untuk Memberikan Interpretasi Koefesien Korelasi (Sugiyono, 2014 :287)

\begin{tabular}{cc}
\hline Interval Koefesien & Tingkat Hubungan \\
\hline $0,00-0,199$ & Sangat Rendah \\
$0,20-0,399$ & Rendah \\
$0,40-0,599$ & Sedang \\
$0,60-0,799$ & Kuat \\
$0,80-1,000$ & Sangat Kuat \\
\hline
\end{tabular}


Pengujian lanjutan yaitu uji signifikan yang berfungsi apabila peneliti mencari makna hubungan variabel $\mathrm{X}$ terhadap $\mathrm{Y}$, maka hasil korelasi PPM tersebut diuji dengan Uji Signifikan dengan rumus:

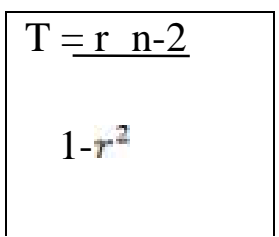

Keterangan: $\mathrm{t}$ hitung $=$ Nilai $\mathrm{t}$

$\mathrm{r}=$ Nilai Koefisien Korelasi

$\mathrm{n}=$ Jumlah Sampel

Uji signifikan korelasi product moment secara praktis, yang tidak perlu di hitung, tetapi langsung dikonsultasikan pada table $r$ product moment. Dengan ketentuannya bila $r$ hitung lebih kecil dari table, maka Ho diterima. Tetapi sebaliknya $\mathrm{r}$ hitung lebih besar dari $r$ table $(r h>r$ tabel) maka ha diterima. Dan untuk pengolahan analisis data ini penulis mengunakan program windows SPSS 20.

\section{c. Uji Hipotesis}

Hipotesis yang akan diujikan dalam penelitian ini adalah sebagai berikut:

1) Regresi Sederhana

Secara umum persamaan regresi sederhana (dengan satu predictor) dapat dirumuskan sebagai berikut :

$$
\begin{aligned}
& \mathrm{Y}=\mathrm{a}+\mathrm{b} \mathrm{X} \\
& \mathrm{Y}=\text { Nilai yang diprediksi }
\end{aligned}
$$

$\mathrm{a}=$ Konstanta atau bila harga $\mathrm{X}=0$

$\mathrm{b}=$ Koefesien regresi

$\mathrm{X}=$ Nilai Variabel Independen

Untuk dapat menemukan persamaan regresi, maka dihitung terlebih dahulu harga $a$ dan $b$ Cara menghitung $a$ dan $b$ dapat mengunakan rumus sebagai berikut :

$$
\begin{aligned}
& \mathrm{a}=\underline{(\Sigma \mathrm{y})\left(\Sigma \mathrm{x}^{2}\right)-(\Sigma \mathrm{x})(\Sigma \mathrm{xy})} \\
& \mathrm{n}\left(\Sigma \mathrm{x}^{2}\right)-(\Sigma \mathrm{x})^{2} \\
& \mathrm{~b}=\underline{\mathrm{n}(\Sigma \mathrm{xy})-(\Sigma \mathrm{x})(\Sigma \mathrm{y})} \\
& \mathrm{n}\left(\Sigma \mathrm{x}^{2}\right)-(\Sigma \mathrm{x})^{2}
\end{aligned}
$$

\section{2) Koefisien Determinan ( $R$ Square)}

Koefesien determinan adalah suatu analisis untuk menguji seberapa besar pengaruh simultan antara kompensasi terhadap kinerja guru.

3) Uji t

Uji $t$ adalah pengujian signifikansi untuk mengetahui pengaruh variabel $\mathrm{X}$ terhadap variabel $\mathrm{Y}$, apakah berpengaruh signifikan atau tidak. Untuk mengetahui hasil signifikan atau tidak dapat dilihat dengan kriteria pengujian :

Jika $t$ tabel $<\mathrm{t}$ hitung maka Ha diterima Jika t hitung > t tabel maka Ho ditolak Berdasarkan hasil signifikansi dengan kriteria sebagai berikut :

Jika signifikansi $>0,01$ maka $\mathrm{Ha}$ diterima

Jika signifikansi $<0,01$ maka Ho ditolak 


\section{HASIL PENELITIAN DAN PEMBAHASAN}

\section{A. Pengujian Persyaratan Analisis}

\section{Uji Normalitas}

\begin{tabular}{llr}
\hline \multicolumn{2}{c}{ One-Sample Kolmogorov-Smirnov Test } & $\begin{array}{c}\text { Unstandardized } \\
\text { Residual }\end{array}$ \\
\hline $\mathrm{N}$ & Mean & 43 \\
Normal Parameters & 0E-b & Std. \\
& Deviation &, 71200243 \\
& Absolute &, 175 \\
Most Extreme Differences & Positive &, 175 \\
& Negative &,- 081 \\
Kolmogorov-Smirnov Z & & 1,150 \\
Asymp. Sig. (2-tailed) & &, 142 \\
a. Test distribution is Normal. & & \\
b. Calculated from data. & &
\end{tabular}

Hasil out put dari one sample besar dari $1 \%(14,2 \%>1 \%)$ maka hipotesis Kolmogorov-Smirnov Test residual, diperoleh diterima dan dengan demikian variabel nilai sig (signifikansi) $0,142=14,2 \%$ dan lebih dependen berdistribusi normal.

\section{Uji Linearitas}



Hasil uji linearitas adalah Sig $\geq 0,01$ di bahwa variabel bebas dengan variabel terikat mana 0,046 $\geq 0,01$ maka dapat disimpulkan mempunyai hubungan yang linear. 


\section{B. Pengujian Hipotesis}

\section{Regresi Linear Sederhana}

\begin{tabular}{|c|c|c|c|c|c|c|}
\hline \multicolumn{7}{|c|}{ Coefficients $^{\mathbf{a}}$} \\
\hline \multirow{2}{*}{\multicolumn{2}{|c|}{ Model }} & Unstan & dardized & Standardized & $\mathrm{t}$ & Sig. \\
\hline & & B & Std Error & Beta & & \\
\hline \multirow[b]{2}{*}{1} & (Constant) & 100,008 & 11,782 & & 8,488 &, 000 \\
\hline & Kompensas & ,378 & 130 & ,413 & 2,905 & ,006 \\
\hline
\end{tabular}

a. Dependent Variable: Kinerja Guru

Dari hasil regresi linear sederhana, diperoleh arah regresi b sebesar 0,378 dan konstanta atau a sebesar 100,008. yaitu kompensasi nilainya adalah 0 , Maka dapat digambarkan bentuk hubungan antara kedua variabel tersebut oleh persamaan regresi:

$$
\begin{aligned}
& \hat{Y}=a+b X \\
& \hat{Y}=100,008+0,378 X
\end{aligned}
$$

Arti dari persamaan regresi ini adalah sebagai berikut :

a. Nilai konstanta (a) adalah 100,008; artinya jika variabel independen maka nilai kinerja guru adalah sebesar 100,008.

b. Nilai koefesien regresi variabel kompensasi (b) adalah 0,378; mengindikasikan bahwa adanya pengaruh positif kompensasi terhadap kinerja guru, di mana setiap peningkatan kompensasi satu satuan akan mengakibatkan peningkatan kinerja guru sebesar 0,378 .

\begin{tabular}{|c|c|c|c|c|}
\hline \multicolumn{5}{|c|}{ Model Summary } \\
\hline Model & $\mathrm{R}$ & R Square & $\begin{array}{l}\text { Adjusted R } \\
\text { Square }\end{array}$ & $\begin{array}{l}\text { Std. Error of the } \\
\text { Estimate }\end{array}$ \\
\hline 1 &, $413^{\mathrm{a}}$ & , 171 &, 150 &, 721 \\
\hline
\end{tabular}

\section{Menghitung Koefisien Determinan}

Hasil output di atas adalah nilai koefesien determinan sebesar 0,171 . Hal ini mengindikasikan bahwa adanya keterlibatan kompensasi terhadap kinerja

\begin{tabular}{|c|c|c|c|c|}
\hline \multicolumn{5}{|c|}{ Coefficients $^{\mathrm{a}}$} \\
\hline Model & $\begin{array}{c}\text { Unstandardized } \\
\text { Coefficients }\end{array}$ & $\begin{array}{l}\text { Standardized } \\
\text { Coefficients }\end{array}$ & $\mathrm{t}$ & Sig. \\
\hline & $\begin{array}{l}\text { B } \quad \text { Std. } \\
\text { Error }\end{array}$ & Beta & & \\
\hline
\end{tabular}

\section{Uji t}




\begin{tabular}{|c|c|c|c|c|c|}
\hline (Constant) & 89,412 & 15,429 & & 5,795 &, 000 \\
\hline $\begin{array}{l}1 \text { Kompens } \\
\text { asi }\end{array}$ &, 378 & , 130 & ,413 & 2,905 & ,006 \\
\hline Dependent & iable: & erja $\mathrm{Gl}$ & & & \\
\hline
\end{tabular}

Berdasarkan tabel output di atas dapat diketahui nilai signifikansi kompensasi terhadap kinerja guru yang diperoleh sebesar 0,006. Hal ini lebih kecil dari 0,01 dan hasil pengujian uji $\mathrm{t}$ menunjukan bahwa nilai $\mathrm{t}$ hitung $>\mathrm{t}$ tabel, di mana untuk menentukan $\mathrm{t}$ tabel dapat dilihat pada tabel statistik pada signifikansi $0,01 / 2=0,005$ dengan derajat kebebasan df $=\mathrm{N}-2$ atau 43-2 $=$ 41. Hasil diperoleh untuk t tabel yaitu 2,701. Dari hasil pengujian dapat diketahui di mana nilai $\mathrm{t}$ hitung sebesar 2,905. Hal ini lebih besar dari t tabel. Disamping itu dengan menggunakan perbandingan $\mathrm{t}$ hitung dan $\mathrm{t}$ tabel, yaitu dengan melakukan perbandingan Sig dengan $\alpha$. Sig $(0,000)<\alpha$, sehingga Ho ditolak. Hasil tersebut menunjukkan bahwa kompensasi berpengaruh signifikan terhadap kinerja guru, dengan demikian pengujian hipotesis pada penelitian ini dapat disimpulkan bahwa Ha diterima dengan asumsi kompensasi berpengaruh terhadap kinerja guru SMPN 3 Batusangkar dan Ho ditolak dengan asumsi kompensasi tidak berpengaruh terhadap kinerja guru SMPN 3 Batusangkar.

\section{KESIMPULAN}

Berdasarkan hasil penelitian yang dilakukan oleh penulis mengenai pengaruh kompensasi terhadap kinerja guru di SMPN 3 Batusangkar dapat disimpulkan bahwa pengaruh yang diberikan kompensasi terhadap kinerja guru adalah $17,1 \%$ dan $82,9 \%$ dari faktor lain. Artinya kompensasi memberikan pengaruh terhadap kinerja guru adalah sebanyak 17,1 \%. Maka kompensasi cukup mempengaruhi kinerja guru di SMPN 3 Batusangkar.

\section{DAFTAR PUSTAKA}

Hasibuan, S.P. M. (2013). Manajemen Sumber Daya Manusia, rev.ed, Jakarta: PT Bumi Aksara

Jasmani dan Mustafa. (2013). Syaiful Supervisi Pendidikan, Yogyakarta: ARRUZZ MEDIA

Nurzaman, Kadar. (2014). Manajemen Personalia, Bandung: CV Pustaka Setia

Prasojo, Dhendhi Bagus. (2012). Pengaruh Pemberian Kompensasi Non Finansial Terhadap Kinerja Guru SMP Negeri Se Kecamatan Bantul, Yogyakarta: Universitas Negeri Yogyakarta

Sugiyono. (2014). Metode Penelitian Manajemen, Bandung, Alfabeta

Supardi. (2013). Kinerja Guru, Jakarta: PT. Raja Grafindo Persada

Torang, Syamsir. (2013). Organisasi \& Manajemen, Bandung: Alfabeta 
Undang-undang no. 14 Tahun 2005 tentang Guru dan Dosen. Jakarta: Sinar Grafika

Wibowo. (2013). Manajemen Kinerja, Jakarta: Rajawali Pers 